\title{
Nutritional fibrous osteodystrophy in goats ${ }^{1}$
}

\author{
Paulo M. Bandarra² ${ }^{2}$ Saulo P. Pavarini ${ }^{2}$, Adriana S. Santos ${ }^{2}$, Nadia Aline B. Antoniassi², \\ Cláudio E.F. Cruz ${ }^{2}$ and David Driemeier ${ }^{2 *}$
}

\begin{abstract}
Bandarra, P.M., Pavarini S.P., Santos A.S., Antoniassi N.A.B., Cruz C.E.F. \& Driemeier D. 2011. Nutritional fibrous osteodystrophy in goats. Pesquisa Veterinária Brasileira 31(10):875-878. Setor de Patologia Veterinária, Faculdade de Veterinária, Universidade Federal do Rio Grande do Sul, Av. Bento Gonçalves 9090, Porto Alegre, RS 91540-000, Brazil. E-mail: davetpat@ufrgs.br

Seven out of 25 goats from a southern Brazilian flock developed nutritional fibrous osteodystrophy. Affected animals were younger than 1 year of age and were confined in stalls and fed a concentrate ration containing 1:6 calcium:phosphorus ratio. The remaining flock (35 goats) was managed at pasture and showed no disease. Clinical signs were characterized by mandibular and maxillary enlargements, varying degrees of mouth opening and protruding tongue, dyspnea, apart of abnormalities of prehension and mastication. Affected animals had increased seric levels of phosphorus and parathormone, as well as higher alkaline phosphatase activity. Postmortem examination on three succumbed goats revealed bilateral enlargement of the maxilla and mandibula, and loose teeth, apart of multiple incomplete rib fractures in one of them. Severe diffuse proliferation of loose connective tissue surrounded the osteoid trabeculae, many of which were partially or completely nonmineralized. Mineralized osteoid trabeculae showed osteoclasts in the Howship's lacunae.
\end{abstract}

INDEX TERMS: Goat diseases, fibrous osteodystrophy, hyperparathyroidism, hyperphosphatemia.

RESUMO.- [Osteodistrofia fibrosa nutricional em caprinos.] Sete de um total de 25 caprinos jovens (menos de um ano de idade) de um rebanho no sul do Brasil desenvolveram osteodistrofia fibrosa nutricional. Os animais afetados eram confinados em baias e alimentados com concentrado, cuja relação Ca:P era 1:6. 0 restante do rebanho (35 cabras) era mantido na pastagem e não desenvolveu a doença. Os sinais clínicos se caracterizaram por aumento de volume da mandibula e maxila, vários graus de abertura de boca com protrusão da língua, em associação com dispneia e anormalidades de apreensão de alimento e mastigação. Os animais afetados apresentaram os níveis séricos de fósforo e paratormônio aumentados, bem como maior atividade de fosfatase alcalina. Três caprinos foram necropsiados e os achados de necropsia incluíram aumento bilateral da maxila e mandíbula, dentes frouxos, além de múltiplas fraturas

\footnotetext{
${ }^{1}$ Received on June 25, 2011.

Accepted for publication on July 11, 2011.

${ }^{2}$ Setor de Patologia Veterinária, Faculdade de Veterinária, Universidade Federal do Rio Grande do Sul (UFRGS), Av. Bento Gonçalves 9090, Porto Alegre, RS 91540-000, Brazil. *Corresponding author: davetpat@ $\underline{\text { ufrgs.br }}$
}

incompletas de costelas em um caprino. Microscopicamente, havia intensa proliferação de tecido conjuntivo frouxo ao redor de trabéculas ósseas, muitas das quais estavam parcial ou completamente não mineralizadas. Trabéculas ósseas mineralizadas apresentaram osteoclastos em lacunas de Howship.

TERMOS DE INDEXAÇÃO: Doenças de caprinos, osteodistrofia fibrosa, hiperparatireoidismo, hiperfosfatemia.

\section{INTRODUCTION}

Fibrous osteodystrophy is a metabolic disorder characterized by extensive bone resorption, proliferation of fibrous connective tissues, and insufficient mineralization of the bone tissues. The pathogenesis involves the persistent increase in the parathormone (PTH) levels in the plasma, what may be associated with primary or secondary hyperparathyroidism (Thompson 2007). Primary hyperparathyroidism is rare in domestic animals and may be linked to parathyroid tumors (adenoma and carcinoma) or idiopathic bilateral parathyroid hyperplasia. However, secondary hyperparathyroidism occurs sporadically and may be attributed to nutritional imbalances or chronic 
renal disease (Weisbrode 2007). Nutritional hyperparathyroidism usually affects young animals fed diets with low calcium and relatively high phosphorus contents. The condition includes decreased concentration of serum ionized calcium and consequent increased synthesis and secretion of PTH (Radostits et al. 2007, Weisbrode 2007). The main clinical manifestations include bone deformities and enlargements, enhanced susceptibility to fractures, and locomotion or postural disturbs (Radostits et al. 2007). Bones, especially those with high rates of renovation such as mandibula and maxilla may develop gradual swollenness and deformities (Woodard 1997). The disease is frequently observed in horses (Radostits et al. 2007) and sporadically described in goats (Andrews et al. 1983, Yates et al. 1987, Aslani et al. 2000), foxes (Pelt \& Caley 1974), pigs, dogs (Kawaguchi et al. 1993), reptiles (Mehler \& Bennett 2003), rabbits (Bas et al. 2005), guinea pigs (Schwarz 2001), cats (Crager \& Nachreiner 1993), lemurs (Tomson \& Lotshaw, 1978), and budgerigars (Arnold et al. 1973); however, it is rare in sheep and cattle (Thompson 2007). This report on nutritional osteodystrophy emphasizes the clinical, biochemical, and pathological alterations observed in affected goats.

\section{MATERIALS AND METHODS}

Epidemiological data and clinical signs of fibrous osteodystrophy were obtained during visits to the farm. Three goats (Goats 1, 8 and 21) were necropsied and specimens of several organs were collected and fixed in buffered formalin $10 \%$. Samples were processed as routinely described in histological analysis and stained with hematoxylin-eosin. Also, bone tissue fragments were stained according to Masson's trichrome technique. Dorsal-ventral mandible and ventral-dorsal maxilla radiographs were taken from Goat 8. Blood serum samples collected from 10 confined goats (Goats 11 to 10 ), and 10 goats kept in pastures (Goats 1 to 20 ) were used to determine serum levels of calcium, phosphorus and alkaline phosphatase enzyme activity. Blood serum samples of Goats $1,2,4,7,8,13,14,15,16$, and 17 were analyzed by chemiluminescence to determine PTH levels. Samples of the feed offered to animals (concentrate and pasture) were used to determine total calcium and phosphorus levels using the humid nitric-perchloric digestion technique, with results expressed as dry sample at $65^{\circ} \mathrm{C}$.

\section{RESULTS}

Seven out of 60 goats managed in a farm located in the county of Cruzeiro do Sul, Rio Grande do Sul, Brazil, presented varied degrees of facial enlargement accompanied by respiratory difficulty and food intake. Of the seven affected animals, four died due to the disease. The seven goats were part of a lot of 25 young animals of less than a year of age that were fed on a diet composed by soybean meal, wheat middlings and green pasture chopped and added in the trough. These goats were kept confined in stalls with lattice floors. The remaining of the herd was formed by 35 goats older than 1 year of age and that were kept in a 3-ha paddock in which oat and ryegrass pastures were established. The seven goats affected with fibrous osteodystrophy presented swollen face (predominantly in the maxilla and in the mandible), partial mouth opening, protruding tongue (Fig.1A,B), difficulty in food retention and mastication, loss of general body condition and dyspnea. Four of these goats eventually died, after a period that on average varied from 15 to 20 days. Calcium and phosphorus analysis revealed calcium:phosphorus ratios (Ca:P) of 1:6 in the concentrate and 2:1 in pastures (Table 1). The confined animals (Goats 1 to 10 ) presented high phosphorus and low calcium serum levels, while the goats that were kept free on the paddock (Goats 11 to 20) presented normal calcium and phosphorus levels (Table 2). The alkaline phosphatase activity was also above normal levels in the confined animals (Goats 1 to 10) and within normal thresholds in the animals that were managed in the pasture (Goats 11 to 20) (Table 2). Apart from this, PTH results were higher in confined animals (Goats 1, 2, 4, 7 e 8), when compared to those from the grazing group (Goats 13 to 17) (Table 2). Three goats on which postmortem examination was made presented marked bilateral enlargement of the maxilla and in the mandible (Fig.1A-C), which were easily sliced using a knife and whose section surfaces were pale. Nasal cavity lumen was decreased due to the thickening of maxillar bones. The teeth were loose and molars were lingually tipped. Also, ribs were softened and broke effortlessly under pressure. One animal (Goat 8) presented several incomplete fractures in ribs. The histopathological exams of the mandible and maxilla revealed accentuated diffuse proliferation of soft and irregular fibrous conjunctive tissue (Fig.1D), which was evinced in the Masson's trichrome staining, around osteoid trabeculae, many of which were partially or completely demineralized. In the mineralized trabeculae, osteoclasts forming multinucleated cells (Fig.1D) were observed in surface grooves (Howship's lacunae). Histological changes were not detected in the renal parenchyma or in the parathyroid glands. Radiological exam of the mandible showed increased and rarefied bone masses, with tooth tipping.

Table 1. Calcium and phosphorus levels in the concentrate and pastures fed to goats

\begin{tabular}{cccc}
\hline & $\begin{array}{c}\text { Total calcium \% } \\
(\mathrm{m} / \mathrm{m})\end{array}$ & $\begin{array}{c}\text { Total phosphorus \% } \\
(\mathrm{m} / \mathrm{m})\end{array}$ & Ca:P \\
\hline Concentrate & 0.09 & 0.57 & 0.16 \\
Pasture & 0.51 & 0.21 & 2.43
\end{tabular}

\section{DISCUSSION}

This case of caprine nutritional osteodystrophy was based on clinical, biochemical, and pathological findings. The nutritional origin of the disease was proved through altered $\mathrm{Ca}: \mathrm{P}$ ration in the diet along with the absence of lesions in parathyroid glands (primary hyperparathyroidism) and renal parenchyma (secondary hyperparathyroidism). The concentrate diet with 6:1 Ca:P ratio was the main nutritional source for the affected goats, while a desirable ratio should be 2:1 (Radostits et al. 2007). It is suggested that the quantity of forage offered to the confined goats was insufficient to establish a balanced Ca:P ratio in the total diet. The excessive intake and consequently increased intesti- 
Table 2. Serum levels of calcium, phosphorus, alkaline phosphatase, and parathormone of goats from a flock affected by nutritional osteodystrophy

\begin{tabular}{ccccccc}
\hline Goat & $\begin{array}{c}\mathrm{Ca} \\
(\mathrm{mg} / \mathrm{dL})\end{array}$ & $\begin{array}{c}\mathrm{P} \\
(\mathrm{mg} / \mathrm{dL})\end{array}$ & $\begin{array}{c}\mathrm{Ca}: \mathrm{P} \\
\text { ratio }\end{array}$ & $\begin{array}{c}\mathrm{AP} \\
(\mathrm{U} / \mathrm{L})\end{array}$ & $\begin{array}{c}\mathrm{PTH} \\
(\mathrm{picog} / \mathrm{mL})\end{array}$ & $\begin{array}{c}\text { Management } \\
\text { system }\end{array}$ \\
\hline 1 & 4.2 & 11.7 & 0.36 & 1004 & 8 & Confined \\
2 & 4.1 & 9.6 & 0.43 & 265 & 27 & Confined \\
3 & 4.9 & 9.3 & 0.53 & 479 & $\mathrm{~N} / \mathrm{A}$ & Confined \\
4 & 4.2 & 13.6 & 0.31 & 486 & 12 & Confined \\
5 & 6.4 & 12.8 & 0.50 & 747 & $\mathrm{~N} / \mathrm{A}$ & Confined \\
6 & 9.9 & 10.6 & 0.93 & 447 & $\mathrm{~N} / \mathrm{A}$ & Confined \\
7 & 4.7 & 6.4 & 0.73 & 308 & 12 & Confined \\
8 & 4.0 & 9.5 & 0.42 & 529 & 156 & Confined \\
9 & 6.4 & 10.1 & 0.63 & 434 & $\mathrm{~N} / \mathrm{A}$ & Confined \\
10 & 9.6 & 8.4 & 1.14 & 767 & $\mathrm{~N} / \mathrm{A}$ & Confined \\
11 & 7.6 & 6.3 & 1.21 & 230 & $\mathrm{~N} / \mathrm{A}$ & Grazing \\
12 & 8.4 & 8.6 & 0.98 & 97 & N/A & Grazing \\
13 & 8.9 & 3.7 & 2.41 & 231 & 3 & Grazing \\
14 & 8.5 & 4.8 & 1.77 & 48 & 3 & Grazing \\
15 & 9.0 & 4.6 & 1.96 & 53 & 3 & Grazing \\
16 & 7.8 & 6.2 & 1.26 & 82 & 3 & Grazing \\
17 & 8.9 & 7.2 & 1.24 & 65 & 3 & Grazing \\
18 & 7.8 & 6.3 & 1.24 & 161 & N/A & Grazing \\
19 & 9.0 & 8.4 & 1.07 & 170 & N/A & Grazing \\
20 & 9.5 & 6.7 & 1.42 & 178 & N/A & Grazing \\
\hline
\end{tabular}

Calcium Ca: 8.9-11.7; phosphorus P: 3.5-6.7; alkaline phosphatase AP: $<387$; parathormone PTH; not available N/A (Kaneko et al. 1997). nal absorption of phosphorus causes hyperphosphatemia, which indirectly stimulates the parathyroid glands by producing hypocalcemia. Compensatory increase in the production and secretion of PTH, which acts in bones, kidneys, and intestines increases calcium absorption (Rosol \& Capen 2008). All the affected goats in this study showed high phosphorus, low calcium, and high PTH serum levels. High activity of alkaline phosphatase is a characteristic laboratorial finding of the condition (Andrews et al. 1983, Radostits et al. 2007), and was observed in most affected goats, but in none of the goats from the grazing group.

Typical clinical signs and gross lesions of the disease usually develop fast in young animals due to their high rates of bone formation and remodeling (Thompson 2007). Only young animals were mismanaged and affected here. Dyspnea observed in affected goats was associated with enlargement of the maxillar bones, which invaded the nasal cavity and, therefore, hindered the air flow. Apprehension and mastication disorders observed in the affected goats may be attributed to the changes in mandible, maxilla, and teeth. Mandible and maxilla enlargements are characteristic alterations in goats affected by fibrous osteodystrophy (Thompson 2007), and the severity of such lesions may be related to the continuous mechanic stimulus of mastication (Thompson 2007). Again, increased numbers of multinucleated osteoclasts in the Howship's lacunae from mineralized trabeculae is a characteristic histological finding of active processes of bone resorption (Thompson 2007), and

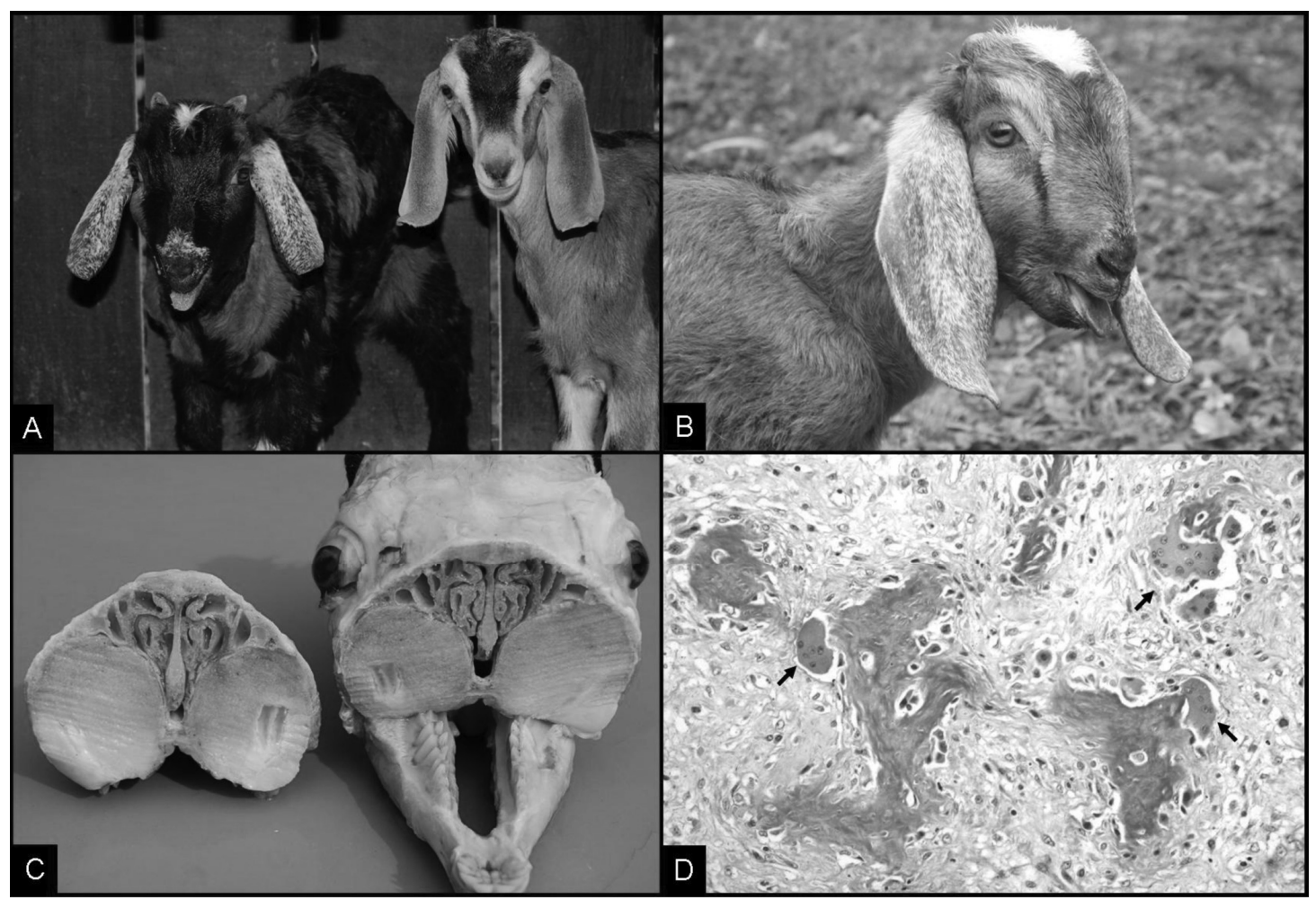

Fig.1. (A,B) Goat kids with severe maxillary enlargements, apart of mouth opening and protruding tongue. (A-C) Marked bilateral enlargement of maxilla and mandibula. (D) Osteoid trabeculae (dark blue areas) surrounded by irregular fibrous conjunctive tissue (pale blue areas); multiple osteoclasts (red) formed multinucleated cells (arrows) on the surface of osteoid trabeculae (Howship's lacunae). Masson's trichrome staining, obj.40x. 
have been described in cases of caprine fibrous osteodystrophy (Andrews et al. 1983). Although it is a well known disorder, this paper includes a well documented case of caprine fibrous osteodystrophy. After correcting the inadequate diet and allowing daily access of the young goats to the pastures, no additional case of disease was noticed in this flock.

Aknowledgements.- This research was funded by Coordenação de Aperfeiçoamento de Pessoal de Nível Superior (CAPES) and Conselho Nacional de Desenvolvimento Científico e Tecnológico (CNPq), Brazil.

\section{REFERENCES}

Andrews A.H., Ingram P.L. \& Longstaffe J.A. 1983. Osteodystrophia fibrosa in young goats. Vet. Rec. 112:404-406.

Arnold S.A., Kram M.A., Hintz H.F., Evans H. \& Krook L. 1973. Nutritional secondary hyperparathyroidism in the parakeet. Cornell Vet. 64:3746.

Aslani M.R., Movassaghi A.R., Mohri M. \& Seifi H.A. 2001. Outbreak of osteodystrophia fibrosa in young goats. J. Vet. Med. A. 48:385-389.

Bas S., Bas A., López I., Estepa J.C., Rodríguez M. \& Aguilera-Tejero E. 2005. Nutritional secondary hyperparathyroidism in rabbits. Domest. Anim. Endocrinol. 28:380-390.

Crager C.S. \& Nachreiner R.F. 1993. Increased parathyroid hormone concentration in a siamese kitten with nutritional secondary hyperparathyroidism. J. Am. Anim. Hosp. Assoc. 29:331-336.

Kaneko J.J., Harvey J.W. \& Bruss M.L. 1997. Clinical Biochemistry of Domestic Animals. $5^{\text {th }}$ ed., Academic Press, San Diego, p.890-894.
Kawaguchi K., Braga 3rd. I.S., Takahashi A., Ochiai K. \& Itakura C. 1993. Nutritional secondary hyperparathyroidism occurring in a strain of German shepherd puppies. Jpn. J. Vet. Res. 41:89-96.

Mehler S.J. \& Bennett R.A. 2003. Oral, dental, and beak disorders of reptiles. Vet. Clin. North. Am., Exot. Anim. Pract. 6(3):477-503.

Pelt R.W. \& Caley M.T. 1974. Nutritional secondary hyperparathyroidism in Alaskan red fox kits. J. Wildl. Dis. 10:47-52.

Radostits O.M., Gay C.C., Hinchcliff K.W. \& Constable P.D. 2007. Veterinary Medicine: A textbook of the diseases of cattle, horses, sheep, pigs, and goats. $10^{\text {th }}$ ed. Saunders, London, p.633-634.

Rosol T.J. \& Capen C.C. 2008. Calcium-Regulating Hormones and Diseases of Abnormal Mineral Metabolism, p.650-652. In: Kaneko J.J., Harvey J.W. \& Bruss M.L. (Eds), Clinical Biochemistry of Domestic Animals. $6^{\text {th }}$ ed. Academic Press, San Diego.

Schwarz T., Störk C.K., Megahy I.W., Lawrie A.M., Lochmüller E.-M. \& Johnston P.E.J. 2001. Osteodystrophia fibrosa in two guinea pigs. J. Am. Vet. Med. Assoc. 219:63-66.

Thompson K. 2007. Bones and Joints, p.82-88. In: Maxie M.G. (Ed.), Jubb, Kennedy, and Palmer's Pathology of Domestic Animals. Vol.1. $5^{\text {th }}$ ed. Elsevier, Philadelphia

Tomson F.N. \& Lotshaw R.R. 1978. Hyperphosphatemia and hypocalcemia in lemurs. J. Am. Vet. Med. Assoc. 173:1103-1106.

Weisbrode S.W. 2007. Bone and joints, p.1075-1076. In: McGavin M.D. \& Zachary J.F. (Eds), Pathologic Basis of Veterinary Disease. $4^{\text {th }}$ ed. Mosby, St Louis.

Woodard J.C. 1997. Skeletal system. p.932-936. In: Jones T.C., Hunt R.D. \& King N.W. (Eds), Veterinary Pathology. $6^{\text {th }}$ ed. Williams and Wilkins, Baltimore.

Yates N.G., Hoffmann D. \& Seripto S. 1987. Mandibular osteodystrophy fibrosa in Indonesian goats fed leucaena. Trop. Anim. Hlth Prod. 19:121-126. 